CRYSTALLOGRAPHIC COMMUNICATIONS

ISSN 2056-9890

Received 15 February 2017

Accepted 9 March 2017

Edited by M. Zeller, Purdue University, USA

Keywords: crystal structure; polycyclic aromatic hydrocarbon; helical molecule.

CCDC reference: 1532540

Supporting information: this article has supporting information at journals.iucr.org/e
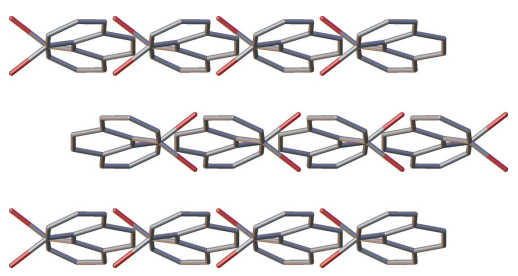

OPEN $\odot$ ACCESS

\section{Crystal structure of 4,5-dibromophenanthrene}

\author{
Nicholas S. Kim and Dasan M. Thamattoor*
}

Department of Chemistry, Colby College, Waterville, ME 04901, USA. *Correspondence e-mail: dmthamat@colby.edu

The synthesis and crystal structure of the title compound, $\mathrm{C}_{14} \mathrm{H}_{8} \mathrm{Br}_{2}$, is described. The molecule is positioned on a twofold rotation axis and the asymmetric unit consists of half a molecule with the other half being generated by symmetry. The presence of two large bromine atoms in the bay region significantly distorts the molecule from planarity and the mean planes of the two terminal rings of the phenanthrene system are twisted away from each other by $28.51(14)^{\circ}$. The torsion angle between the two $\mathrm{C}-\mathrm{Br}$ bonds is $74.70(14)^{\circ}$ and the distance between the two $\mathrm{Br}$ atoms is 3.2777 (13) $\AA$. The molecules pack in layers in the crystal, with the centroids of the central rings of the phenanthrene units in adjacent layers separated by a distance of 4.0287 (10) $\AA$. These centroids are shifted by 2.266 (6) $\AA$ relative to each other, indicating slippage in the stacking arrangement. Furthermore, the distance between the centroids of the terminal and central rings of the phenanthrene units in adjacent layers is slightly shorter at 3.7533 (19) $\AA$. While all of the molecules within each layer are oriented in the same direction, those in adjacent layers are oriented in the opposite direction, leading to anti-parallel stacks.

\section{Chemical context}

In the course of our research into non-planar polycyclic hydrocarbons, we became interested in the preparation of helical phenanthrene systems bearing bulky substituents in the 4- and 5-positions. Towards that end, we undertook the synthesis of 4,5-dibromophenanthrene (2) from the known dialdehyde 1 (Suzuki et al., 2009) using a recently published procedure (Xia et al., 2012), as shown in Fig. 1. Although there is one reference to the title compound $\mathbf{2}$ in the literature (Cosmo et al., 1987a), neither the procedure for its synthesis nor its X-ray crystal structure has previously been reported.

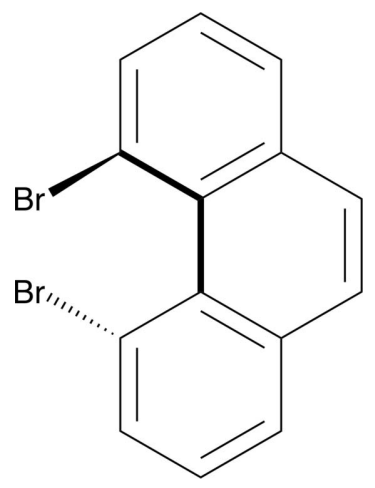

\section{Structural commentary}

The asymmetric unit consists of half a molecule with the other half generated by symmetry as the molecule is positioned on a 
<smiles>O=Cc1cccc(Br)c1-c1c(Br)cccc1C=O</smiles>

1

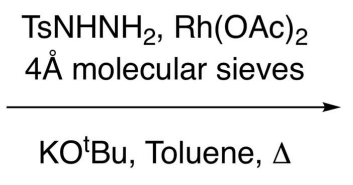

Figure 1

Synthesis of 4,5-dibromophenanthrene (2).

twofold rotation axis that bisects the central ring. The crystal structure shows a deformed phenanthrene framework (Fig. 2) in which the planes of the two terminal rings are twisted away from each other by $28.51(14)^{\circ}$ and the torsion angle between the two $\mathrm{C}-\mathrm{Br}$ bonds $\left(\mathrm{Br} 1-\mathrm{C} 4-\mathrm{C}^{\prime}-\mathrm{Br} 1^{\prime}\right)$ is $74.70(14)^{\circ}$. The $\mathrm{C} 4-\mathrm{C} 5-\mathrm{C}^{\prime}-\mathrm{C}^{\prime}$ torsion angle is $32.8(6)^{\circ}$, and the distance between the two bromine atoms is 3.277 (13) $\AA$, a value consistent with a previous report (Cosmo et al., 1987a). A comparison of the key structural features of the title compound 2 to those of other known 4,5-dihalophenanthrenes (Cosmo et al., 1987b; Bock et al., 1998) is presented in Table 1 with reference to the general structure shown in Fig. 3. The

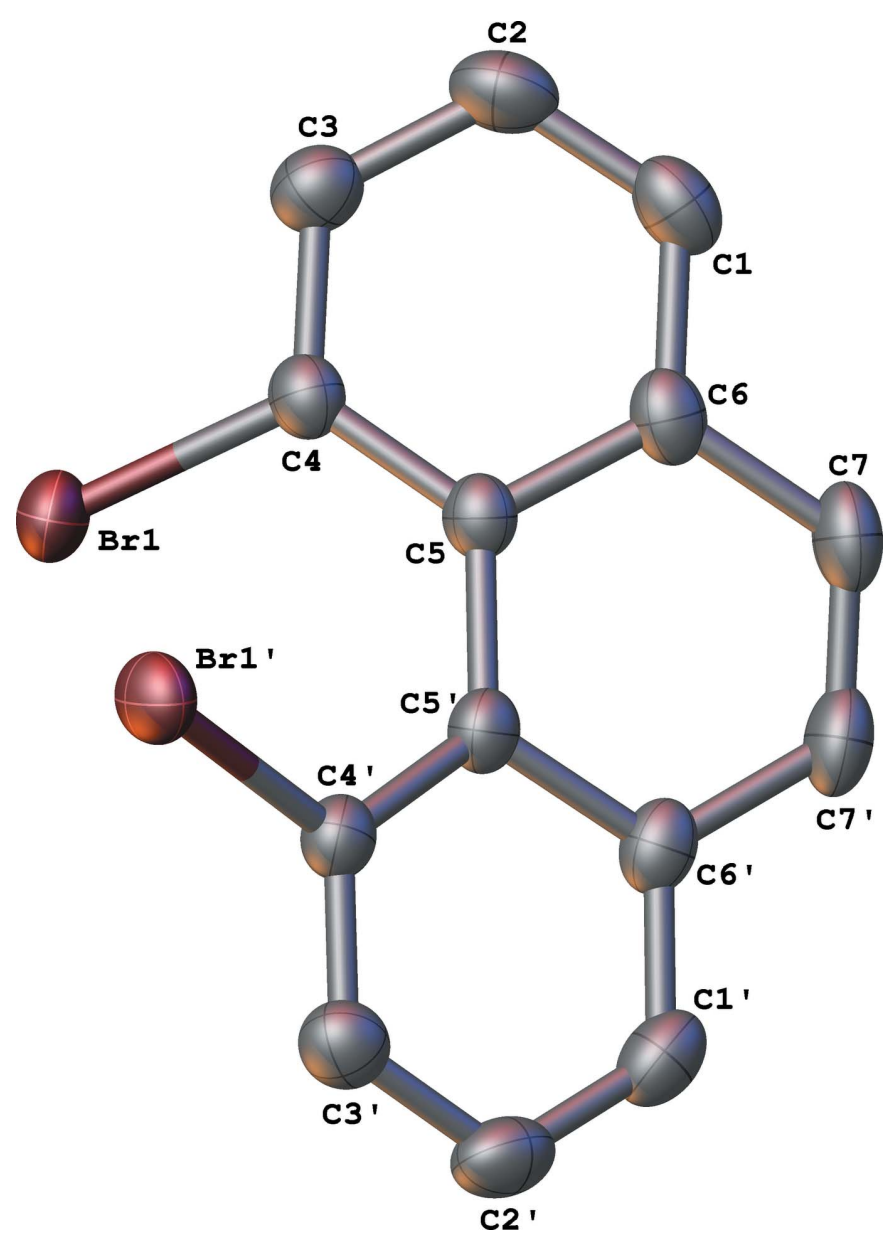

Figure 2

Crystal structure of 2 with displacement ellipsoids shown at the $50 \%$ probability level. $\mathrm{H}$ atoms omitted for clarity. [Symmetry code: (') $1-x,+$ $\left.y, \frac{3}{2}-z\right]$
Table 1

A comparison of selected structural parameters $\left(\AA,^{\circ}\right)$ in a series of known 4,5-dihalophenanthrene derivatives.

Refer to Fig. 3 for parameters used in this table.

\begin{tabular}{lllll}
\hline Compound & $\begin{array}{l}\text { angle between } \\
\text { rings } A \text { and } C\end{array}$ & $\begin{array}{l}X \cdots X \\
\text { distance }\end{array}$ & $\begin{array}{l}\mathrm{C} 4-\mathrm{C}^{\prime}-\mathrm{C}^{\prime}-\mathrm{C} 5 \\
\text { torsion angle }\end{array}$ & $\begin{array}{l}X-\mathrm{C} 4-\mathrm{C} 5-X \\
\text { torsion angle }\end{array}$ \\
\hline $\mathbf{3}(X=\mathrm{F})^{a}$ & 16.779 & 2.381 & 19.954 & 43.273 \\
$\mathbf{4}(X=\mathrm{Cl})^{a}$ & 32.282 & 3.097 & 37.738 & 69.980 \\
$\mathbf{2}(X=\mathrm{Br})^{b}$ & $28.51(14)^{b}$ & $3.277(13)^{c}$ & $32.8(6)$ & $74.70(14)$ \\
$\mathbf{5}(X=\mathrm{I})^{d}$ & 29.451 & 3.610 & 33.716 & 78.611 \\
\hline
\end{tabular}

Notes: (a) Cosmo et al. (1987b); (b) this work; (c) Cosmo et al. 1987(a); (d) Bock et al. (1998).

distance between the two halogen atoms, and the torsion angle between the two carbon-halogen bonds $(X-\mathrm{C} 4-\mathrm{C} 5-X)$, increase as expected with the increasing size of the halogen atom. Interestingly, however, the distortion of the phenanthrene framework, as measured by either the angle between the mean planes of the terminal rings $A$ and $C$, or the $\mathrm{C} 4-$ $\mathrm{C}^{\prime}{ }^{\prime}-\mathrm{C}^{\prime}$ - $-\mathrm{C} 5$ torsion angle (see Fig. 3), is the largest for the dichloro derivative 4 (Table 1), larger than for the dibromo and diodo compounds. A combination of both size and electronegativity may account for compound $\mathbf{4}$ showing the largest twist of the phenanthrene system in the series of 4,5-dihalophenathrene compounds.

\section{Supramolecular features}

A view of the crystal packing diagram, along the $b$ axis, shows the centroids of the central $B$ rings of the phenanthrene units

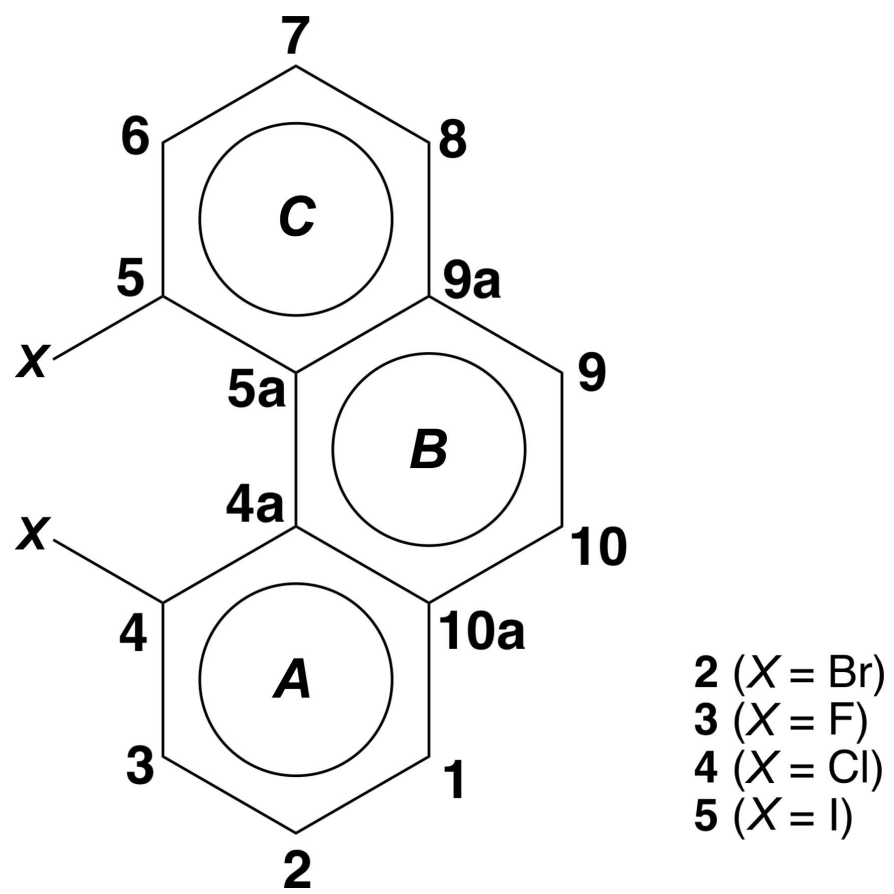

Figure 3

The 4,5-dihalo derivatives of phenanthrene shown with conventional chemical numbering. This figure is used as a reference for the data in Table 1. 

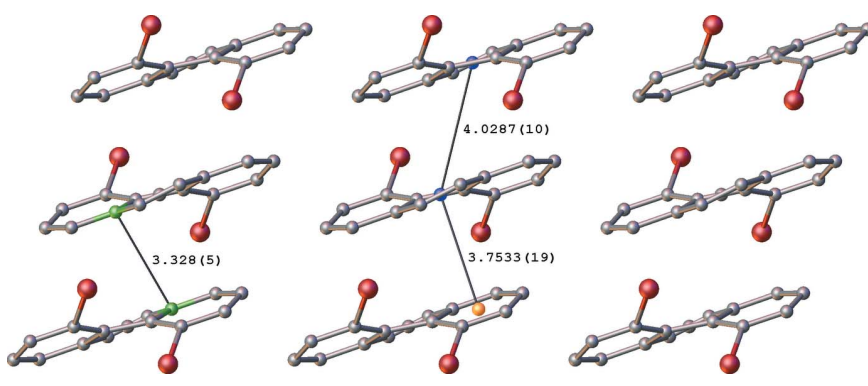

Figure 4

Crystal packing of $\mathbf{2}$ when viewed along the $b$ axis. The separation between the centroids of the middle rings (blue spheres) is slightly longer than that between the centroids of the middle and terminal rings (blue and orange spheres) in adjacent layers. Close contacts are also observed between equivalent carbon atoms in the terminal rings (shown in green) that are offset from each other. All lengths are in $\AA$.

in adjacent layers (marked in blue in Fig. 4, see Fig. 3 for ring numbering), separated by a distance of 4.0287 (10) $\AA$. These (blue) centroids are shifted by 2.266 (6) $\AA$ relative to each other, indicating a slippage in the stacking arrangement. This ring slippage is also evidenced by the centroid of the $B$ ring being at a shorter distance of 3.7533 (19) $\AA$ to the $A$ ring centroid (shown in orange in Fig. 4) of the closest phenanthrene unit in an adjacent layer. In addition, short contacts of 3.328 (5) $\AA$ are found between C6 (or C6'; refer to Fig. 2. for atom numbering) and an equivalent carbon atom in an adjacent layer. These atoms, which are in terminal rings offset from each other, are shown in green in Fig. 4. A view along the $a$ axis (Fig. 5) shows the opposing orientation of the molecules in going from one layer to the next, leading to anti-parallel stacks.

\section{Database survey}

The Cambridge Structural Database (CSD, Version 5.38, update November 2016; Groom et al., 2016) reveals entries for 4,5-difluorophenanthrene (refcode: FIXWOY; Cosmo et al., 1987a), 4,5-dichlorophenanthrene (refcode: FIXWUE; Cosmo et al.,1987b), and 4,5-diiodophenanthrene (refcode: PIPRUB;
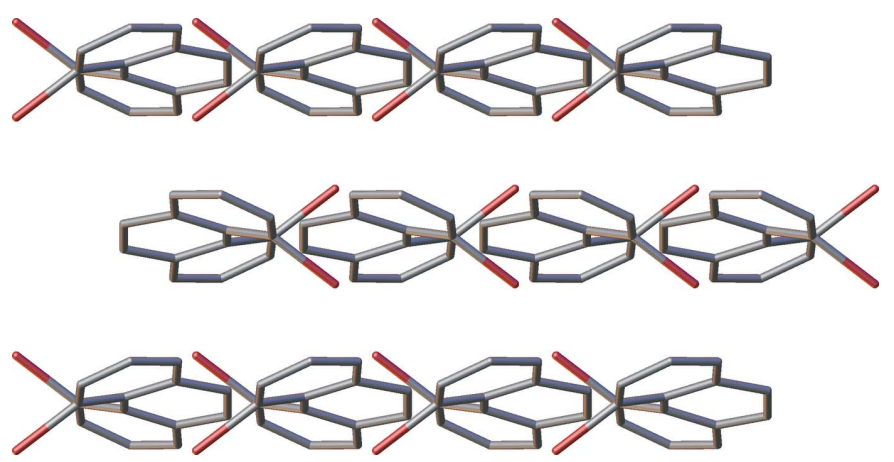

Figure 5

Crystal packing of $\mathbf{2}$ when viewed along the $a$ axis, showing the opposite orientation of molecules in alternating layers.
Table 2

Experimental details.

\begin{tabular}{|c|c|}
\hline \multicolumn{2}{|l|}{ Crystal data } \\
\hline Chemical formula & $\mathrm{C}_{14} \mathrm{H}_{8} \mathrm{Br}_{2}$ \\
\hline$M_{\mathrm{r}}$ & 336.02 \\
\hline Crystal system, space group & Monoclinic, $C 2 / c$ \\
\hline Temperature $(\mathrm{K})$ & 173 \\
\hline$a, b, c(\AA)$ & $16.840(3), 8.6112(16), 8.1418(15)$ \\
\hline$\beta\left(^{\circ}\right)^{2}$ & $103.735(2)$ \\
\hline$V\left(\AA^{3}\right)$ & $1146.9(4)$ \\
\hline$Z$ & 4 \\
\hline Radiation type & Мо $K \alpha$ \\
\hline$\mu\left(\mathrm{mm}^{-1}\right)$ & 7.03 \\
\hline Crystal size $(\mathrm{mm})$ & $0.25 \times 0.11 \times 0.07$ \\
\hline \multicolumn{2}{|l|}{ Data collection } \\
\hline Diffractometer & Bruker D8 QUEST ECO \\
\hline Absorption correction & $\begin{array}{l}\text { Multi-scan (SADABS; Krause et } \\
\quad \text { al., 2015) }\end{array}$ \\
\hline$T_{\min }, T_{\max }$ & $0.47,0.64$ \\
\hline $\begin{array}{l}\text { No. of measured, independent and } \\
\text { observed }[I>2 \sigma(I)] \text { reflections }\end{array}$ & $4708,1203,1070$ \\
\hline$R_{\text {int }}$ & 0.033 \\
\hline$(\sin \theta / \lambda)_{\max }\left(\AA^{-1}\right)$ & 0.634 \\
\hline \multicolumn{2}{|l|}{ Refinement } \\
\hline$R\left[F^{2}>2 \sigma\left(F^{2}\right)\right], w R\left(F^{2}\right), S$ & $0.030,0.083,1.06$ \\
\hline No. of reflections & 1203 \\
\hline No. of parameters & 73 \\
\hline $\mathrm{H}$-atom treatment & $\mathrm{H}$-atom parameters constrained \\
\hline$\Delta \rho_{\max }, \Delta \rho_{\min }\left(\mathrm{e} \AA^{-3}\right)$ & $1.01,-0.35$ \\
\hline
\end{tabular}

Computer programs: APEX3 (Bruker, 2016), SAINT (Bruker, 2015), SHELXS2013 (Sheldrick, 2008), SHELXL2014 (Sheldrick, 2015), OLEX2 (Dolomanov et al., 2009) and publCIF (Westrip, 2010).

Bock et al.,1998). The title compound, 4,5-dibromophenanthrene (2), however, is not in the database.

\section{Synthesis and crystallization}

The dialdehyde 1 (108 $\mathrm{mg}, 0.3 \mathrm{mmol}), p$-toluenesulfonyl hydrazide $(114 \mathrm{mg}, 0.6 \mathrm{mmol})$, and toluene $(2 \mathrm{~mL})$ were successively added to a flame-dried flask under argon. The milky white mixture was heated at $333 \mathrm{~K}$ and stirred for $10 \mathrm{~min}$. More toluene $(14 \mathrm{~mL})$ was added, and the solution was cooled to room temperature. Then, $4 \AA$ molecular sieves (100 mg), KO ${ }^{t} \mathrm{Bu}$ (100 mg, $\left.0.9 \mathrm{mmol}\right), \mathrm{Rh}_{2}(\mathrm{OAc})_{4} \quad(2 \mathrm{mg}$, $0.005 \mathrm{mmol})$, and toluene $(14 \mathrm{~mL})$ were added successively. The reaction system was degassed with argon and the resulting solution was stirred at $363 \mathrm{~K}$ for $1 \mathrm{~h}$, producing a deep brownred color after $20 \mathrm{~min}$. The mixture was cooled to room temperature and the crude product was purified by silica gel column chromatography to give $\mathbf{2}$, as colorless crystals (24 mg, $0.07 \mathrm{mmol}, 23 \%)$. m.p. 443-444 K; ${ }^{1} \mathrm{H}$ NMR $(500 \mathrm{MHz}$, $\left.\mathrm{CDCl}_{3}\right) \delta 7.40(m, 1 \mathrm{H}), 7.50(m, 1 \mathrm{H}), 7.70(m, 1 \mathrm{H}), 7.80(m$, 1H). ${ }^{13} \mathrm{C}$ NMR $\left(125 \mathrm{MHz}, \mathrm{CDCl}_{3}\right) \delta 135,132,129,128,127$, 126, 122. LRMS (EI) $m / z \quad 335.9\left(M^{+}\right), 255,176$. Crystals suitable for X-ray analysis were grown by the slow diffusion of pentane into a concentrated solution of $\mathbf{2}$ in dichloromethane.

\section{Refinement}

Crystal data, data collection and structure refinement details are summarized in Table 2. 


\section{Acknowledgements}

We thank Dr Bruce Noll of Bruker for providing helpful suggestions in the course of drafting this manuscript.

\section{Funding information}

Funding for this research was provided by: National Science Foundation, Directorate for Mathematical and Physical Sciences (award No. CHE-1300937); Office of the Provost, Colby College, Waterville, ME 04901.

\section{References}

Bock, H., Sievert, M. \& Havlas, Z. (1998). Chem. Eur. J. 4, 677-685. Bruker (2015). SAINT. Bruker AXS, Inc. Madison, Wisconsin, USA.
Bruker (2016). APEX3. Bruker AXS, Inc. Madison, Wisconsin, USA. Cosmo, R., Hambley, T. W. \& Sternhell, S. (1987a). Tetrahedron Lett. 28, 6239-6240.

Cosmo, R., Hambley, T. W. \& Sternhell, S. (1987b). J. Org. Chem. 52, 3119-3123.

Dolomanov, O. V., Bourhis, L. J., Gildea, R. J., Howard, J. A. K. \& Puschmann, H. (2009). J. Appl. Cryst. 42, 339-341.

Groom, C. R., Bruno, I. J., Lightfoot, M. P. \& Ward, S. C. (2016). Acta Cryst. B72, 171-179.

Krause, L., Herbst-Irmer, R., Sheldrick, G. M. \& Stalke, D. (2015). J. Appl. Cryst. 48, 3-10.

Sheldrick, G. M. (2008). Acta Cryst. A64, 112-122.

Sheldrick, G. M. (2015). Acta Cryst. C71, 3-8.

Suzuki, T., Yoshimoto, Y., Takeda, T., Kawai, H. \& Fujiwara, K. (2009). Chem. Eur. J. 15, 2210-2216.

Westrip, S. P. (2010). J. Appl. Cryst. 43, 920-925.

Xia, Y., Liu, Z., Xiao, Q., Qu, P., Ge, R., Zhang, Y. \& Wang, J. (2012). Angew. Chem. Int. Ed. 51, 5714-5717. 


\section{supporting information}

Acta Cryst. (2017). E73, 539-542 [https://doi.org/10.1107/S2056989017003863]

\section{Crystal structure of 4,5-dibromophenanthrene}

\section{Nicholas S. Kim and Dasan M. Thamattoor}

\section{Computing details}

Data collection: APEX3 (Bruker, 2016); cell refinement: SAINT (Bruker, 2015); data reduction: SAINT (Bruker, 2015); program(s) used to solve structure: SHELXS2013 (Sheldrick, 2008); program(s) used to refine structure: SHELXL2014 (Sheldrick, 2015); molecular graphics: OLEX2 (Dolomanov et al., 2009); software used to prepare material for publication: publCIF (Westrip, 2010).

4,5-Dibromophenanthrene

Crystal data

$\mathrm{C}_{14} \mathrm{H}_{8} \mathrm{Br}_{2}$

$M_{r}=336.02$

Monoclinic, $C 2 / c$

$a=16.840(3) \AA$

$b=8.6112(16) \AA$

$c=8.1418(15) \AA$

$\beta=103.735(2)^{\circ}$

$V=1146.9(4) \AA^{3}$

$Z=4$

Data collection

Bruker D8 QUEST ECO diffractometer

Radiation source: sealed tube, Siemens KFFMO2K-90C

Curved graphite monochromator Detector resolution: 8.3660 pixels $\mathrm{mm}^{-1}$ $\omega$ and $\varphi$ scans

Absorption correction: multi-scan

(SADABS; Krause et al., 2015)

\section{Refinement}

Refinement on $F^{2}$

Least-squares matrix: full

$R\left[F^{2}>2 \sigma\left(F^{2}\right)\right]=0.030$

$w R\left(F^{2}\right)=0.083$

$S=1.06$

1203 reflections

73 parameters

0 restraints
$F(000)=648$

$D_{\mathrm{x}}=1.946 \mathrm{Mg} \mathrm{m}^{-3}$

Mo $K \alpha$ radiation, $\lambda=0.71073 \AA$

Cell parameters from 3136 reflections

$\theta=2.5-26.8^{\circ}$

$\mu=7.03 \mathrm{~mm}^{-1}$

$T=173 \mathrm{~K}$

Block, clear colourless

$0.25 \times 0.11 \times 0.07 \mathrm{~mm}$

$T_{\min }=0.47, T_{\max }=0.64$

4708 measured reflections

1203 independent reflections

1070 reflections with $I>2 \sigma(I)$

$R_{\text {int }}=0.033$

$\theta_{\text {max }}=26.8^{\circ}, \theta_{\text {min }}=2.5^{\circ}$

$h=-21 \rightarrow 21$

$k=-10 \rightarrow 10$

$l=-10 \rightarrow 10$

Hydrogen site location: inferred from neighbouring sites

$\mathrm{H}$-atom parameters constrained

$w=1 /\left[\sigma^{2}\left(F_{\mathrm{o}}^{2}\right)+(0.0557 P)^{2}+0.5337 P\right]$

where $P=\left(F_{\mathrm{o}}{ }^{2}+2 F_{\mathrm{c}}{ }^{2}\right) / 3$

$(\Delta / \sigma)_{\max }=0.005$

$\Delta \rho_{\max }=1.01 \mathrm{e} \AA^{-3}$

$\Delta \rho_{\min }=-0.35$ e $\AA^{-3}$ 


\section{Special details}

Geometry. All esds (except the esd in the dihedral angle between two 1.s. planes) are estimated using the full covariance matrix. The cell esds are taken into account individually in the estimation of esds in distances, angles and torsion angles; correlations between esds in cell parameters are only used when they are defined by crystal symmetry. An approximate (isotropic) treatment of cell esds is used for estimating esds involving l.s. planes.

Fractional atomic coordinates and isotropic or equivalent isotropic displacement parameters $\left(\AA^{2}\right)$

\begin{tabular}{lllll}
\hline & $x$ & $y$ & $z$ & $U_{\text {iso }} * / U_{\text {eq }}$ \\
\hline Br1 & $0.41183(2)$ & $0.94243(3)$ & $0.60761(4)$ & $0.03791(16)$ \\
C1 & $0.35716(18)$ & $0.4938(4)$ & $0.8748(4)$ & $0.0403(7)$ \\
H1 & 0.34 & 0.3985 & 0.914 & $0.048^{*}$ \\
C2 & $0.31143(18)$ & $0.6255(4)$ & $0.8762(4)$ & $0.0440(7)$ \\
H2 & 0.2652 & 0.6234 & 0.9242 & $0.053^{*}$ \\
C3 & $0.33332(16)$ & $0.7628(4)$ & $0.8065(4)$ & $0.0384(6)$ \\
H3 & 0.2992 & 0.8517 & 0.7974 & $0.046^{*}$ \\
C5 & $0.45980(15)$ & $0.6426(3)$ & $0.7686(3)$ & $0.0295(6)$ \\
C4 & $0.40447(15)$ & $0.7692(3)$ & $0.7508(3)$ & $0.0313(5)$ \\
C6 & $0.42910(17)$ & $0.4984(3)$ & $0.8160(3)$ & $0.0332(6)$ \\
C7 & $0.46876(18)$ & $0.3558(3)$ & $0.7880(4)$ & $0.0400(7)$ \\
H7 & 0.4503 & 0.2602 & 0.8239 & $0.048^{*}$ \\
\hline
\end{tabular}

Atomic displacement parameters $\left(\AA^{2}\right)$

\begin{tabular}{lllllll}
\hline & $U^{11}$ & $U^{22}$ & $U^{33}$ & $U^{12}$ & $U^{13}$ & $U^{23}$ \\
\hline Br1 & $0.0421(2)$ & $0.0281(2)$ & $0.0447(2)$ & $0.00648(10)$ & $0.01255(15)$ & $0.00529(10)$ \\
C1 & $0.0409(16)$ & $0.0388(16)$ & $0.0393(16)$ & $-0.0115(14)$ & $0.0055(12)$ & $0.0039(13)$ \\
C2 & $0.0334(14)$ & $0.055(2)$ & $0.0458(17)$ & $-0.0090(14)$ & $0.0138(12)$ & $-0.0033(14)$ \\
C3 & $0.0327(13)$ & $0.0406(16)$ & $0.0411(15)$ & $0.0008(12)$ & $0.0073(11)$ & $-0.0026(12)$ \\
C5 & $0.0313(12)$ & $0.0261(13)$ & $0.0296(13)$ & $-0.0020(10)$ & $0.0041(10)$ & $-0.0016(9)$ \\
C4 & $0.0336(13)$ & $0.0275(13)$ & $0.0323(12)$ & $-0.0021(10)$ & $0.0069(10)$ & $-0.0008(10)$ \\
C6 & $0.0361(14)$ & $0.0290(14)$ & $0.0309(13)$ & $-0.0031(12)$ & $0.0006(11)$ & $0.0027(11)$ \\
C7 & $0.0508(17)$ & $0.0229(13)$ & $0.0420(16)$ & $-0.0040(11)$ & $0.0027(13)$ & $0.0012(11)$ \\
\hline
\end{tabular}

Geometric parameters $\left(\stackrel{A}{\circ}{ }^{\circ}\right)$

\begin{tabular}{llll}
\hline $\mathrm{Br} 1-\mathrm{C} 4$ & $1.916(3)$ & $\mathrm{C} 3-\mathrm{H} 3$ & 0.95 \\
$\mathrm{C} 1-\mathrm{C} 2$ & $1.373(5)$ & $\mathrm{C} 5-\mathrm{C} 4$ & $1.419(4)$ \\
$\mathrm{C} 1-\mathrm{C} 6$ & $1.405(4)$ & $\mathrm{C} 5-\mathrm{C} 6$ & $1.433(4)$ \\
$\mathrm{C} 1-\mathrm{H} 1$ & 0.95 & $\mathrm{C} 5-\mathrm{C} 5^{\mathrm{i}}$ & $1.456(5)$ \\
$\mathrm{C} 2-\mathrm{C} 3$ & $1.398(5)$ & $\mathrm{C} 6-\mathrm{C} 7$ & $1.441(4)$ \\
$\mathrm{C} 2-\mathrm{H} 2$ & 0.95 & $\mathrm{C} 7-\mathrm{C} 7^{\mathrm{i}}$ & $1.341(6)$ \\
$\mathrm{C} 3-\mathrm{C} 4$ & $1.379(4)$ & $\mathrm{C} 7-\mathrm{H} 7$ & 0.95 \\
$\mathrm{C} 2-\mathrm{C} 1-\mathrm{C} 6$ & & & $117.96(17)$ \\
$\mathrm{C} 2-\mathrm{C} 1-\mathrm{H} 1$ & $120.7(3)$ & $\mathrm{C} 6-\mathrm{C} 5-\mathrm{C} 5^{\mathrm{i}}$ & $122.5(3)$ \\
$\mathrm{C} 6-\mathrm{C} 1-\mathrm{H} 1$ & 119.6 & $\mathrm{C} 3-\mathrm{C} 4-\mathrm{C} 5$ & $114.7(2)$ \\
$\mathrm{C} 1-\mathrm{C} 2-\mathrm{C} 3$ & 119.6 & $\mathrm{C} 3-\mathrm{C} 4-\mathrm{Br} 1$ & $121.6(2)$
\end{tabular}




$\begin{array}{llll}\mathrm{C} 1-\mathrm{C} 2-\mathrm{H} 2 & 120.2 & \mathrm{C} 1-\mathrm{C} 6-\mathrm{C} 5 & 120.8(3) \\ \mathrm{C} 3-\mathrm{C} 2-\mathrm{H} 2 & 120.2 & \mathrm{C} 1-\mathrm{C} 6-\mathrm{C} 7 & 120.0(3) \\ \mathrm{C} 4-\mathrm{C} 3-\mathrm{C} 2 & 120.0(3) & \mathrm{C} 5-\mathrm{C} 6-\mathrm{C} 7 & 119.0(3) \\ \mathrm{C} 4-\mathrm{C} 3-\mathrm{H} 3 & 120.0 & \mathrm{C} 7-\mathrm{C} 7-\mathrm{C} 6 & 121.13(18) \\ \mathrm{C} 2-\mathrm{C} 3-\mathrm{H} 3 & 120.0 & \mathrm{C} 7-\mathrm{C} 7-\mathrm{H} 7 & 119.4 \\ \mathrm{C} 4-\mathrm{C} 5-\mathrm{C} 6 & 115.0(2) & \mathrm{C} 6-\mathrm{C} 7-\mathrm{H} 7 & \\ \mathrm{C} 4-\mathrm{C} 5-\mathrm{C} 5 & & 4.9(4) \\ & 126.84(17) & & -169.4(3) \\ \mathrm{C} 6-\mathrm{C} 1-\mathrm{C} 2-\mathrm{C} 3 & & & -13.0(4) \\ \mathrm{C} 1-\mathrm{C} 2-\mathrm{C} 3-\mathrm{C} 4 & -9.9(4) & \mathrm{C} 2-\mathrm{C} 1-\mathrm{C} 6-\mathrm{C} 5 & 171.6(3) \\ \mathrm{C} 2-\mathrm{C} 3-\mathrm{C} 4-\mathrm{C} 5 & -3.9(4) & \mathrm{C} 4-\mathrm{C} 5-\mathrm{C} 6-\mathrm{C} 7 & 161.3(2) \\ \mathrm{C} 2-\mathrm{C} 3-\mathrm{C} 4-\mathrm{Br} 1 & 164.5(2) & \mathrm{C} 5-\mathrm{C} 5-\mathrm{C} 6-\mathrm{C} 1 & -14.1(4) \\ \mathrm{C} 6-\mathrm{C} 5-\mathrm{C} 4-\mathrm{C} 3 & 12.2(4) & \mathrm{C} 4-\mathrm{C} 5-\mathrm{C} 6-\mathrm{C} 7 & 171.4(3) \\ \mathrm{C} 5-\mathrm{C} 5-\mathrm{C} 4-\mathrm{C} 3 & -172.8(3) & \mathrm{C} 5-\mathrm{C} 5-\mathrm{C} 6-\mathrm{C} 7 & -2.9(5) \\ \mathrm{C} 6-\mathrm{C} 5-\mathrm{C} 4-\mathrm{Br} 1 & -154.6(2) & \mathrm{C} 1-\mathrm{C} 6-\mathrm{C} 7-\mathrm{C} 7^{\mathrm{i}} & \\ \mathrm{C} 5-\mathrm{C} 5-\mathrm{C} 4-\mathrm{Br} 1 & 20.4(4) & \mathrm{C} 5-\mathrm{C} 6-\mathrm{C} 7-\mathrm{C} 7^{\mathrm{i}} & \end{array}$

Symmetry code: (i) $-x+1, y,-z+3 / 2$.

$?$ 